\title{
REVIEW JURNAL KAJIAN PENELITIAN ILMU KOMUNIKASI DAN INFORMASI
}

\author{
JIAN ADHA ARIESTANTO \\ : C1B117150 \\ KOMANG AGUSETIAWAN \\ : C1B117155 \\ NONI EKA PUTRI \\ : C1B117199 \\ RAODATUL JANNAH \\ : C1B117209
}

PROGRAM STUDI ILMU PEMERINTAHAN

FAKULTAS ILMU SOSIAL DAN ILMU POLITIK

UNIVERSITAS HALU OLEO

1. Promosi Kuliner Jepang Melalui Media Sosial Sebagai Bentuk Diplomasi Publik : Studi Facebook Kedutaan Besar Jepang di Indonesia

Pergeseran menuju era digitalisasi informasi menandai kondisi politik internasional saat ini. Pada konteks hubungan internasional, hal ini terkait pada situasi di mana melalui instrumen diplomasi aspek informasi dan teknologi memainkan peranan penting pada upaya pencapaian kepentingan nasional. Awalnya diplomasi antar aktor dalam politik internasional yang semula berfokus pada upaya pencapaian kepentingan nasional menggunakan jalur-jalur tradisional, seperti negosiasi formal antar perwakilan negara, tekanan ekonomi dan militer. Dan pada perkembangannya telah bergeser menjadi diplomasi yang berbasis internet di mana upaya pencapaian kepentingan nasional suatu negara tidak lagi dipengaruhi oleh kekuatan hard seperti militer dan ekonomi, namun bisa menggunakan media sosial. (Mansbach, 2003)

Di jaman serba canggih ini diplomasi yang dilakukan tidak harus seperti halnya diatas melainkan bisa menggunakan media sosial entah itu facebook ataupun instagram. Sama halnya yang dilakukan negara Jepang terhadap negara Indonesia yang melakukan diplomasi dalam bentuk mempublikasikan kuliner khas jepang melalui media sosial. Dilakukannya diplomasi antar negara agar hubungan negara satu dengan lain tetap terjaga dan tidak terpecah bela dan tentunya saling menguntungkan satu sama lain. 
Tujuan yang ingin dicapai yaitu bagaimana respon masyarakat terhadap pempublikasian makanan khas jepang ini dan seberapa tertariknya karena yang menjadi target utama negara jepang ialah masyarakat indonesia sebagai pengguna media sosial yang terbilang cukup banyak. Selain hal diatas yang menjadi tujuan selanjutnya ialah seberapa penting peran teknologi dalam hal diplomasi antar negara guna mencapai tujuan yang sama.

Jurnal ini menggunakan metode penelitian deskriptif kualitatif dengan subjek penelitian ialah media sosial Facebook Kedutaan Besar Jepang di Indonesia. Sedangkan teknik pengumpulan data dilakukan melalui wawancara, dan dokumentasi. Dalam penelitian ini yang menjadi informan yaitu admin Facebook Kedutaan Besar Jepang di Indonesia dan salah satu anggota Sekretariat Little Tokyo World Cosplay Summit Indonesia Kommitte. Adapun teknik analisa data yang digunakan dalam penelitian ini adalah analisis model interaktif yang berisi tahapan pengumpulan data, reduksi data, penyajian data, dan simpulan (Miles, Huberman, \& Saldana, 2014 ).

Diplomasi digital dalam kaitannya dengan diplomasi suatu negara, dapat diamati dalam dua level utama, yaitu tingkat Kementerian Luar Negeri, dan tingkat perwakilan Kedutaan Besar. Dengan dua tingkatan tersebut, diplomasi melalui media sosial dianggap mampu membantu negara dalam mencapai tujuannya, seperti upaya membentuk citra atau nation branding. Diplomasi melalui media sosial juga dipandang sebagai instrumen yang efektif dalam upaya menjaga reputasi suatu negara (image management) karena dianggap mampu menghadirkan komunikasi dua arah diantara penggunanya. (Bjola \& Holmes, 2015). Dalam hal penggunaan media sosial sebagai alat mendukung kegiatan diplomasi publik, media sosial seperti Facebook dan Instagram dianggap mampu menjalin hubungan dengan publik secara lebih luas. Adapun keterlibatan media sosial dengan publik dapat dilihat dari tiga hal utama, yaitu dalam hal digital agenda setting, presence expansion, dan digital conversation generating.

Selain menyediakan informasi resmi, tujuan Kedutaan Besar Jepang menyediakan akun Facebook adalah untuk menjaga dialog dengan para pengikut dan untuk menyampaikan reaksi terutama terhadap upaya penyampaian informasi palsu tentang Kedutaan Besar Jepang dan untuk menuliskannya kembali cerita yang benar. Pemerintah Jepang dalam hal ini juga berusaha untuk menjaga hubungan yang dekat dengan Indonesia dengan mengadakan berbagai kegiatan yang berkaitan 
dengan hubungan bilateral. Selain itu, di dalam laman Facebook juga dapat ditemukan berbagai berita dari kegiatan Kedutaan Besar Jepang di Indonesia.

Fitur-fitur yang disampaikan di akun Instagram lebih banyak berupa fotofoto dan berbagai kegiatan, dan sesekali juga ditampilkan pertemuan di belakang layar dari aktivitas diplomasi. Deskripsi dari berbagai postingan disampaikan dalam bahasa Indonesia.

Saran yang dapat diberikan kepada penulis jurnal yaitu untuk lebih memperhatikan dampak negatif diadakannya diplomasi seperti halnya diatas, karena kita ketahui bersama masyarakat indonesia mayoritas muslim dan salah satu kebutuhan dasarnya berupa makanan yang sudah pasti halal. Penulis juga harus memikirkan jika diadakannya diplomasi seperti ini ditakutkan masyarakat indonesia nantinya lebih memilih atau lebih menyukai kuliner khas negara lain dibanding negara nya sendiri.

\section{Promosi Pariwisata Melalui Digital Diplomasy: Upaya Internasional}

\section{Pariwisata Daerah}

E-diplomasi (juga dikenal sebagai diplomasi digital) adalah penggunaan teknologi komunikasi dan informasi untuk tujuan mencapai kebijakan luar negeri (Holmes, 2013). E-diplomasi secara sederhana bagaimana membuat kebijakan satu negara dipahami dan diterima oleh negara lain. Hubungan luar negeri Pemerintah Daerah Kabupaten Wakatobi tercermin dalam berbagai kerjasama dengan beberapa negara seperti Sister City dengan pemerintah Provinsi Jeju, Korea Selatan, kerjasama dengan pemerintah Swiss, serta kerjasama dengan Japan Internasional Cooperation Agency (JICA) (Beritasatu.com, 2015; Kontan.co.id, 2015; Pemerintah Wakatobi, 2014).

Dalam pengelolaan website ternyata masih ditemui kendala mengoperasikannya. Beberapa kendala tersebut seperti ketersediaan sumber daya manusia yang berkutat di industri ini masih rendah. Masih sedikit ditemukan studi yang mengeksplor mengenai diplomasi digital sebagai instrument promosi wisata dalam level pemerintah daerah dibanding dengan studi yang membahas tentang implementasi fungsi teknologi informasi dan komunkasi dalam area pelayanan publik seperti e government, e planning, e budgeting. Oleh karena itu perlunya studi yang membahas tentang penggunaan internet dan media sosial 
dalam diplomasi digital oleh Pemerintah Daerah. Studi ini akan lebih fokus membahas mengenai promosi wisata daerah Wakatobi di kancah internasional melalui diplomasi digital.

Tujuan dari penelitian jurnal yaitu guna membahas tentang bagaiaman peran website dalam memberikan data dan infromasi yang dapat dipercaya mengenai perkembangan Parwisata Kabupaten Wakatobi, kegiatan-kegiatan atau agenda pariwisata, akses keterangan destinasi. Tentu saja informasi yang disajikan dari website terebut tidak hanya memiliki fungsi sebagai sarana penyebaran informasi bagi publik Kabupaten wakatobi namun juga untuk daerah lain termasuk dari luar negeri.

Jurnal ini menggunakan metode penelitian kualitatif guna mengetahui dan mengungkap fenomena yang terjadi. Wawancara digunakan sebagai sumber data dengan jumlah informan sebanyak tiga orang. Informan dalam penelitian ialah pegawai pada kantor Dinas Pariwisata dan Ekonomi Kretaif Kabupaten Wakatobi. Data primer dalam studi ini bersumber dari hasil wawancara, sedangkan data sekunder didapatkan dari website dan media sosial yang digunakan Dinas Pariwisata dan Ekonomi Kreatif pemerintah Kabupaten Wakatobi dalam mempromosikan pariwisata Wakatobi.

Hasil dari penelitian ini menunjukan pengguanaan TIK dalam sektor pariwisata merupakan instrumen penting dalam melakukan aktivitas bisnis, maupun pemasaran oleh satu organisasi kepada khalayak mengingat itu adalah cara yang baru dan begitu efektif untuk berinteraksi dan memberikan informasi kepada pengguna layanan ataupun jasa karena memungkinkan interaksi antara pemberi layanan atau jasa dan customer lebih dalam. Internet telah menjadi saluran distribusi utama dalam e-tourism hal ini seperti yang dilakukan oleh Dinas Pariwisata dan Ekonomi Kreatif Kabupaten Wakatobi memanfaatkan media intenet sebagai salah satu media untuk mempromosikan pariwisata daerah. Dalam konteks ini diplomasi digital mempromosikan penggunaan TIK untuk memenuhi kebijakan suatu daerah sebagai upaya untuk memberikan informasi tidak hanya dalam negeri tapi juga luar negeri. Selain itu diplomasi pemerintah daerah pemerintah Wakatobi juga dilakukan dengan mengikuti berbagai acara-acara internasional seperti pameran diberbagai negara.

Selan itu penggunaan media sosial juga menjadi alat bagi pemerintah daerah dalam mempromosikan pariwisata daerah Wakatobi seperti penggunaan 
Facebook, Instagram dan Twitter. Media sosial ini dimanfaatkan oleh pemerintah daerah dan untuk memberikan informasi terkait kepariwisataan kepada wisatawan asing diberbagai belahan dunia. Selain menggunakan media sosial Dinas Pariwisata dan Ekonomi Kreatif Wakatobi menggunakan website resmi dalam memberikan informasi mengenai pariwisata Wakatobi. Website ini menggunakan dua Bahasa yaitu Inggris dan Indonesia. Keberadaan layanan World Wide Web (WWW) memungkinkan pemerintah daerah untuk terus berinovasi dalam memanfaatkan TIK. Bahasa utama yang digunakan yaitu bahasa inggris yang mencakup seluruh pariwisata wakatobi yaitu dari akses ke Wakatobi, kegiatankegiatan wisata yang dilakukan di Wakatobi, akses keterangan destinasi pariwisata dan akses terkait akomodasi. Pemerintah Daerah Kabupaten Wakatobi melalui Dinas Pariwisata dan Ekonomi Kreatif Kabupaten Wakatobi dalam upayanya untuk mempromosikan pariwisata telah menggunakan media internet sebagai salah satu instrumen diplomasi digital.

Saran yang dapat diberikan terhadap jurnal penelitian ini yaitu, Dalam hal mempromosikan suatu destinasi daerah seperti daerah Wakatobi memanglah bagus jika menggunakan bahasa inggris yang dikenal sebagai bahasa internasional, namun lain lagi jika pengguna media sosial atau website tidak begitu paham terhadap bahasa yang digunakan yaitu bahasa inggris, dan juga salah satu tujuan dipromosikannya suatu destinasi ini bukan hanya kepada masyarakat luar negeri saja tetapi masyarakat dalam negeri bahkan masyarakat sekitar daerah Wakatobi tersebut membutuhkannya. Peneliti harus lebih memperhatikan hal-hal kecil seperti ini karena tidak semua pengguna media sosial paham dengan bahasa inggris.

\section{REFERENCES}

1. Ramadhan, W. O. J., Sudirman, F. A., Saidin, S., \& Susilawaty, F. T. (2020). Promosi Kuliner Jepang Melalui Media Sosial Sebagai Bentuk Diplomasi Publik: Studi Facebook Kedutaan Besar Jepang di Indonesia. Jurnal Ilmu Komunikasi UHO: Jurnal Penelitian Kajian Ilmu Komunikasi dan Informasi, 5(1), 63-75

2. Sudirman, F. A., Sarma, W. O. D., \& Susilawaty, F. T. PROMOSI PARIWISATA MELALUI DIGITAL DIPLOMACY: UPAYA INTERNASIONALISASI 
PARIWISATA DAERAH. Jurnal Ilmu Komunikasi UHO: Jurnal Penelitian Kajian Ilmu Komunikasi dan Informasi, 5(3), 174-185. 